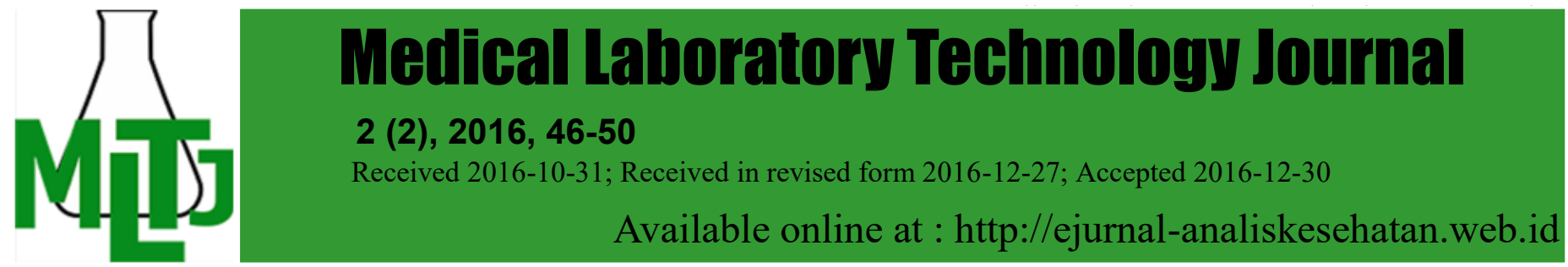

\title{
KADAR SIANIDA SINGKONG REBUS DAN SINGKONG GORENG
}

\author{
Yeni Purwati, Anny Thuraidah, Dinna Rakhmina \\ Jurusan Analis Kesehatan Poltekkes Kemenkes Banjarmasin \\ JI Mistar Cokrokusumo 4a Banjarbaru \\ e-mail: dinnapoltekesbjm@gmail.com
}

\begin{abstract}
Cassava is the third staple food often used by people to make a variety of products. Carbohydrates from cassava also contains toxic compound such as cyanide which can inhibit the action of respiratory enzymes. Cyanide in cassava can be removed by boiling or frying process. The aim of research was to find out the cyanide level differences between boiled cassava and fried cassava. This type of research was experiment, with design of comparative studies approach. Cyanide levels were examined in 10 samples with 2 treatments using Argentometry Volhard titration method. The result showed the average of cyanide levels in boiled cassava was $0.772 \mathrm{ppm}$ and in fried cassava was $1.069 \mathrm{ppm}$. The percentage of cyanide levels reduction in boiled cassava was $28,78 \%$, while for the fried cassava was $0 \%$. The statistical test obtained the value of $p<0.05$, that showed there was significant difference of cyanide level between boiled cassava and fried cassava. Based on these results, it is advisable to choose the boiling process for cassava consumption. Next research can be conducted on comparative levels of cyanide in the cassava root and cassava leaves.
\end{abstract}

Keywords: Cyanide; Boiled cassava; Fried cassava

Abstrak: Singkong adalah bahan pokok ketiga yang sering dimanfaatkan oleh masyarakat dengan berbagai macam produk. Karbohidrat singkong juga mengandung racun berupa asam sianida yang dapat menghambat kerja enzim pernapasan. Sianida pada singkong dapat dihilangkan dengan proses perebusan atau pengorengan. Tujuan penelitian untuk mengetahui perbedaan kadar sianida pada singkong rebus dan singkong goreng. Jenis penelitian berupa eksperimen, dengan rancangan pendekatan studi komparatif. Dilakukan pemeriksaan kadar sianida pada 10 sampel dengan 2 perlakuan menggunakan metode titrasi Argentometri Volhard. Dari hasil pemeriksaan diperoleh rata-rata kadar sianida pada singkong rebus 0,772 ppm dan pada singkong goreng $1,069 \mathrm{ppm}$. Sedangkan persentase penurunan kadar sianida pada singkong rebus adalah $28,78 \%$ dan singkong goreng $0 \%$. Selanjutnya dengan uji statistik diperoleh nilai $p<0,05$ yang menumjukkan adanya perbedaan bermakna antara singkong rebus dengan singkong goreng. Berdasarkan hasil penelitian ini, maka disarankan memilih proses perebusan untuk konsumsi singkong. Peneliti selanjutnya dapat dilakukan penelitian mengenai perbandingan kadar sianida pada umbi dan daun singkong.

Kata kunci: Sianida; Singkong Rebus; Singkong Goreng. 


\section{PENDAHULUAN}

Makanan merupakan kebutuhan pokok bagi makhluk hidup termasuk manusia. Makanan bagi manusia mempunyai fungsi, antara lain sebagai penghasil energi, untuk pertumbuhan, membentuk sel-sel tubuh dan menggantikan sel-sel tubuh yang rusak. Dengan demikian makanan yang dikonsumsi hendaknya makanan yang bergizi tinggi. Makanan yang bergizi yaitu makanan yang mengandung zat-zat yang diperlukan oleh tubuh yaitu : karbohidrat, lemak, protein, mineral dan air dalam jumlah seimbang. Karbohidrat adalah sumber energi utama yang diperlukan oleh tubuh. Sumber karbohidrat banyak terdapat dalam biji-bijian dan umbiumbian. Salah satu makanan kaya akan karbohidrat yaitu singkong yang termasuk dalam golongan umbi-umbian (Amalia, 2011).

Di Indonesia singkong dijadikan sebagai bahan makanan pokok ketiga setelah padi dan jagung. Selain bahan makanan pokok, macam-macam produk olahan singkong dapat dimanfaatkan oleh masyarakat, antara lain adalah tape singkong, eyek-eyek singkong, opak, kerupuk singkong, gethuk serta tepung tapioka (Sunarto, 2002).

Selain mengandung karbohidrat, singkong juga mengandung racun yang disebut sianida. Asam sianida adalah racun yang dapat menghambat kerja enzim pernapasan sehingga terjadi gangguan pernapasan yang dapat menyebabkan sakit dan kematian. Bila dicerna, hidrogen sianida sangat cepat terserap oleh alat pencernaan dan masuk ke dalam aliran darah. Dalam sel-sel singkong terdapat enzim yang dapat memecah glikosida sianogenik menghasilkan HCN (Hidrogen sianida) bebas dan bersifat sangat beracun (Sunarto, 2002).

Untuk menghindari keracunan sianida pada singkong diperlukan pengolahan seperti dicuci, direndam, direbus, dikukus, digoreng, atau dibakar. Perebusan adalah proses pemasakan dengan menggunakan media air, sedangkan penggorengan adalah proses pemasakan menggunakan media minyak.

Pengolahan singkong dengan cara pemanasan menggunakan perebusan dapat menguapkan sianida sehingga akan mempercepat penurunan kadar sianida, dengan mempercepat dehidrasi dan pemecahan struktur sel, sehingga terjadi degradasi glukosida linamarin $\left(\mathrm{C}_{10} \mathrm{H}_{17} \mathrm{O}_{6} \mathrm{~N}\right)$ dalam singkong oleh enzim linamarase yang menghasilkan glukosa dan aceton sianohidrin, kemudian melepaskan hidrogen sianida (Twetongyere dan Katonhole dalam Yuningsih, 2009).

Singkong goreng memerlukan minyak yang panas sebagai medianya. Di dalam minyak sianida tidak larut, namun karena adanya pemanasan yang tinggi, sianida akan menguap dan akan menurunkan sebagian kadar sianida didalam singkong tersebut.

Penelitian terdahulu menyebutkan bahwa perendaman dan perebusan singkong yang berulang hanya dapat menghilangkan kadar sianida 50\% (Purawisastra dkk, 2012). Namun belum ada data mengenai kadar sianida pada singkong goreng. Penelitian ini bertujuan untuk mengetahui perbedaan kadar sianida pada singkong rebus dan singkong goreng.

\section{BAHAN DAN METODE}

Jenis penelitian berupa eksperimen, dengan rancangan pendekatan secara studi komparatif (Notoatmodjo, 2012), yaitu membandingkan kadar sianida yang direbus dengan kadar sianida yang digoreng, dilakukan pemeriksaan kadar sianida pada 10 sampel dengan 2 perlakuan, kemudian dilakukan 2 kali pengulangan (duplo) pada tiaptiap pemeriksaan.

Penelitian dilakukan di Laboratorium Dasar Fakultas MIPA Universitas Lambung Mangkurat. Waktu penelitian pada bulan Maret 2016. Singkong yang digunakan berasal dari pasar banjarbaru. Variabel bebas penelitian ini adalah singkong rebus dan singkong goreng. Variabel terikat dalam penelitian ini adalah kadar sianida. Pemeriksaan sianida menggunakan metode Argentometri cara Volhard.

Sampel singkong Kelompok (1) adalah singkong tanpa proses perebusan dan tanpa proses penggorengan. Kelompok (2) adalah singkong yang direbus dalam $200 \mathrm{ml}$ air sampai memdidih selama 10 menit. Kelompok (3) adalah singkong yang digoreng hingga warna singkong menjadi kuning kecoklatan.

Analisa Kuantitatif dilakukan dengan cara menimbang $10 \mathrm{~g}$ sampel yang sudah ditumbuk halus, ditambahkan $100 \mathrm{ml}$ aquades dalam labu kjeldhal dan didiamkan selama 2 jam. Kemudian ditambahkan lagi $100 \mathrm{ml}$ aquades dan didestilasi dengan uap. Destilat ditampung di tampung dalam erlenmayer yang telah diisi dengan $20 \mathrm{ml} \mathrm{AgNO}_{3} 0,02 \mathrm{~N}$ dan $1 \mathrm{ml} \mathrm{HNO}_{3}$. 
Setelah destilat mencapai $100 \mathrm{ml}$, destilat dihentikan. Destilat kemudian disaring, endapan yang mungkin ada dicuci dengan aquadest. Kelebihan $\mathrm{AgNO}_{3}$ dalam destilat dititrasi dengan KCNS memakai indikator ferri ammonium sulfat. Standarisasi larutan $\mathrm{AgNO}_{3}$ dilakukan dengan larutan $\mathrm{NaCl} 0,02 \mathrm{~N}$. Standarisasi larutan KCNS dilakukan dengan larutan $\mathrm{AgNO}_{3} 0,02 \mathrm{~N}$

\section{HASIL DAN PEMBAHASAN}

Hasil pengukuran kadar sianida pada singkong dapat dilihat pada tabel dibawah.

Hasil pengukuran kadar sianida pada singkong dapat dilihat pada tabel 1.

Tabel 1. Kadar Sianida pada Singkong

\begin{tabular}{cccc}
\hline NO & $\begin{array}{c}\text { Kontrol (Tanpa } \\
\text { Perlakuan) }(\mathrm{ppm})\end{array}$ & $\begin{array}{c}\text { Singkong Rebus } \\
(\mathrm{ppm})\end{array}$ & $\begin{array}{c}\text { Singkong Goreng } \\
(\mathrm{ppm})\end{array}$ \\
\hline 1 & 1,296 & 0,756 & 1,296 \\
2 & 0,81 & 1,188 & 0,81 \\
3 & 1,242 & 1,08 & 1,242 \\
4 & 0,702 & 0,81 & 0,702 \\
5 & 0,864 & 0,594 & 0,864 \\
6 & 1,242 & 0,702 & 1,242 \\
7 & 0,81 & 0,594 & 0,81 \\
8 & 1,188 & 0,81 & 1,188 \\
9 & 1,404 & 0,756 & 1,404 \\
10 & 1,134 & 0,432 & 1,134 \\
rata-rata & 1,069 & 0,772 & 1,069 \\
\hline
\end{tabular}

Penurunan rata-rata pada masing-masing kelompok dapat dilihat pada gambar berikut:

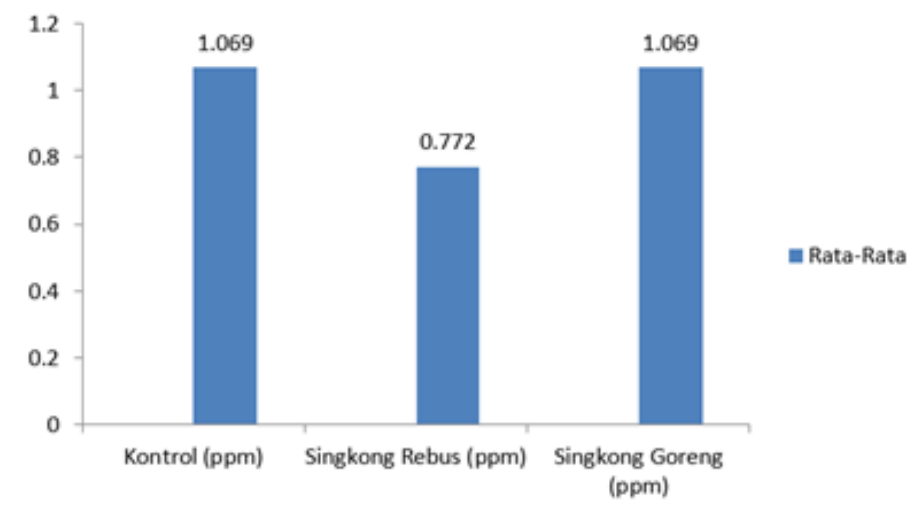

Gambar 1 Rata-rata Kadar Sianida masing-masing kelompok perlakuan

Tabel.2 Persentase Penurunan kadar Sianida terhadap control

\begin{tabular}{ccc}
\hline No & $\begin{array}{c}\text { Perlakuan Sampel } \\
\text { Singkong }\end{array}$ & $\begin{array}{c}\text { Persentase Penurunan } \\
\text { Kadar Sianida }\end{array}$ \\
\hline 1 & Perebusan & $27,78 \%$ \\
2 & Penggorengan & $0 \%$ \\
\hline
\end{tabular}

Uji normalitas dengan Shapiro-Wilk memperoleh nilai sig $=0,188$ atau sig $>0,05$ yang artinya data tersebut berdistribusi normal sehingga digunakan uji-t tidak berpasangan. Hasil uji-t tidak berpasangan didapatkan sig. $0,012<\alpha(0,05)$ sehingga terdapat perbedaan yang bermakna antara singkong rebus dengan singkong goreng. Perbedaan bermakna juga terdapat antara singkong rebus terhadap singkong tanpa perlakuan (kontrol) dengan nilai sig. 0,012 < a $(0,05)$, namun tidak ada perbedaan pada singkong goreng terhadap singkong tanpa pengolahan dengan nilai sig 1,000 > $\alpha(0,05)$.

Pemanasan memiliki kelebihan antara lain prosesnya cepat, relatif mudah, dan bisa dilakukan dengan biaya murah. $\mathrm{HCN}$ adalah asam yang bersifat volatile, dengan pemanasan senyawa ini akan mudah menguap. HCN juga memiliki sifat kelarutan yaitu sangat mudah larut dalam air (Pambayun, 2007). Oleh karena HCN mudah menguap karena panas dan mudah larut dalam air, peneliti memilih perebusan dan penggorengan sebagai perlakuan dalam penelitian ini.

Hasil penelitian menunjukkan bahwa perebusan dapat menurunkan kadar sianida dalam singkong sebesar $27,78 \%$ sedangkan pada singkong yang digoreng tidak mengalami penurunan kadar sianida, hal ini disebabkan karena pada sampel singkong yang di goreng dengan perlakukan singkong setelah dikupas dicuci langsung di goreng tanpa ada perendaman dengan air terlebih dahulu dan pada saat digoreng singkong hanya dipanaskan sampai kuning kecoklatan yang membuat singkong tersebut kurang matang dan menyebabkan tidak mengalami penurunan kadar sianida pada sampel singkong goreng.

$$
\text { Jaringan tanaman singkong }
$$
mengandung suatu enzyme hidrolase yang dikenal sebagai linamarase ( $\beta$ glukosidase). Ketika jaringan akar singkong rusak, terutama oleh perlakuan mekanik (proses persiapan bahan baku atau proses persiapan produk) atau oleh aktivitas microbial (proses fermentasi), enzim linamarase kontak dengan linamarin, akibatnya linamarin akan terhidrolisa dan melepaskan hidrogen sianida. Hidrolisis linamarin melibatkan dua tahapan reaksi yakni pembentukan senyawa intermediate acetonsianohidrin, yang akan secara spontan terurai atau oleh aksi enzim hidroxinitrilelyase membentuk aceton dan hidrogen sianida (Yeoh dalam Hartati, 2008). 
Pada tanaman singkong, linamarase terletak pada dinding sel tanaman. Ketika jaringan tanaman dirusak atau dicacah, linamarase akan terekspos dengan linamarin sehingga melepaskan senyawa sianida yang bisa berakibat fatal jika dikonsumsi. Pada tubuh manusia, keracunan akut akan cenderung terejadi dibandingikan kematian. Aksi dari enzim digunakan pada berbagai kebudayan untuk memproses singkong sehingga menjadi bahan yang dapat dikonsumsi manusia. Enzim linamarase akan mengkonversi senyawa yang mengandung sianida menjadi aceton sianohidrin, yang secara spontan akan terdekomposisi menjadi hidrogen sianida ( $\mathrm{HCN})$. Selanjutnya $\mathrm{HCN}$ akan larut dalam air atau dilepaskan ke udara. Selama proses pengolahan singkong, tidak semua sianida dapat dihilangkan. Linamarase diketahui optimum pada $\mathrm{pH} \mathrm{5,1} \mathrm{-} 6$ dan dapat dihambat oleh $\mathrm{pH}$ rendah melalui larutan asam (Food Standards Australia New Zaeland, 2004).

Pemanasan memiliki dwifungsi, menginaktifkan enzim dan menguapkan $\mathrm{HCN}$ yang terbentuk karena senyawa ini sifatnya volatile. Pemanasan akan menyebabkan enzimb-glukosidase yang berada dalam umbi (sitoplasma selular) mengalami inaktif sehingga rantai enzimatis dapat diputus. Jika reaksi itu diputus, pembentukansianohidrin dari glukosida sianogenik dan reaksi pembentukan $\mathrm{HCN}$ dari sianohidrin bisa dihindari.

Proses perebusan menjamin seluruh permukaan umbi terjadi kontak langsung dengan air rebusan, juga terjadi penguapan dan kerusakan oleh air panas, pemanasan dalam air mendidih dapat mengakibatkan enzim linamarase dan glukosidase tidak aktif sehingga pembentukan asam sianida terputus. sehingga rerata kadar HCN yang terukur lebih rendah (Paggara, 2010). Pemanasan dan air merupakan cara pengolahan yang dapat menurunkan sifat sianogenik karena $\mathrm{HCN}$ dapat menguap dengan pemanasan dan $\mathrm{HCN}$ juga luruh dengan adanya air. Ini dapat dibuktikan pada penelitian pada perebusan didapatkan penurunan kadar sianida $27,78 \%$.

Pada proses penggorengan digunakan minyak sebagai media penghantar panas, HCN senyawa yang mudah menguap karena adanya pemanasan. Namun dalam penelitian ini tidak terjadi penurunan kadar sianida $(0 \%)$. Hal ini terjadi karena linamarin tidak terhidrolisis menjadi HCN akibat sifat dari minyak yang menghambat dekomposisi produk senyawa linamarin menjadi aceton sianohidrin yang bersifat racun didalam tubuh. Pada per- lakuan digoreng juga hanya dicuci sesaat saja sampai kotoran yang ada di umbi singkong hilang dan tidak dilakukan perendaman dengan air, kemudian singkong digoreng sampai kuning kecoklatan muda yang menyebabkan singkong kurang matang.

Bukan hanya itu minyak yang bersifat nonpolar tidak dapat melarutkan HCN yang merupakan senyawa polar hal ini menyebabkan $\mathrm{HCN}$ tidak dapat larut didalam minyak. Sejatinya senyawa polar dapat larut didalam pelarut polar dan senyawa nonpolar dapat larut didalam pelarut nonpolar (Kataren, 2008). Menurut (Baskin dkk, 2008) sianida hanya dapat larut didalam air dan semua pelarut organik (nonpolar).

Pada penelitian Ojiako dan Chikezie (2013) menyebutkan tidak ada perbedaan pada sampel masakan garri (masakan dari Nigeria terbuat dari singkong) yang ditambahkan minyak dalam fermentasi, tetapi penelitian dari Olorunfemi dan Afobhokhan (2012) juga menyebutkan bahwa minyak mempengaruhi penurunan kadar sianida pada sampel yang diberi perlakuan dengan minyak.Perbedaan ini disebabkan pada penelitian Ojiako dan Chikezie yaitu sampel yang tidak ditumbuk dan durasi fermentasi sampel yang digoreng dengan minyak relatif singkat yaitu ( $t \leq 48$ jam) dibandingkan pada penelitian Olorunfemi dan Afobhokhan dengan sampel yang ditumbuk terlebih dahulu dan durasi fermentasi lebih lama ( $t>72$ jam).

Hal ini sejalan dengan penelitian ini dimana kadar sianida singkong dengan perlakuan digoreng menggunakan minyak tidak mengalami penurunan karena singkong yang digoreng masih dalam ukuran besar-besar, digoreng dengan waktu yang relatif singkat yakni sampai singkong berubah warna menjadi kuning kecoklatan.

Penelitian Purawisasta menyebutkan penurunan kadar sianida akibat perlakuan rata-rata sebesar $50 \%$, berbeda dengan penelitian ini yang hanya mendapatkan penurunan kadar sianida sebesar $27,78 \%$ dan $0 \%$. Penelitian purawisastra menggunakan metode pengeringan diatas sinar matahari beberapa hari sehingga kadar air turun hingga $10 \%$ kemudian ditumbuk hingga terbentuk tepung, setelah itu kadar sianida dianalisis dengan metode Argentometri Volhard. Perbedaan dengan penelitian ini yaitu pada perlakuan singkong masih dalam ukuran yang besar-besar, tidak dilakukkan proses pemanasan dan perebusan yang lama. 
Penelitian Amalia tahun 2011 juga menyebutkan penurunan kadar sianida dengan perebusan dengan waktu dari 0 menit sampai 15 menit sebesar : $37,3 \%, 15$ sampai 30 menit : 23,6\%, 30 sampai 45 menit : 38,9\%. Dan penurunan kadar sianida yang mengalami proses pengukusan 0 sampai 15 menit : $19,5 \%$, 15 sampai 30 menit : $23,8 \%$, 30 sampai 45 menit : $31,5 \%$. Untuk itu dengan perlakuan dan waktu yang berbeda akan memberikan hasil penurunan kadar sinida yang berbeda. Semakin lama perlakuan maka semakin besar penurunan kadar sianida di dalam singkong.

Pada penelitian ini didapatkan rata-rata kadar sianida adalah singkong rebus 0,772 ppm; singkong goreng 1,069 ppm; dan singkong tanpa pengolahan 1,069 ppm. Kadar singkong rebus, goreng ataupun mentah masih dalam batas aman untuk dikonsumsi yaitu $<50 \mathrm{ppm}$. Tetapi yang digunakkan dalam penelitian ini adalah jenis singkong (Manihot sp), tetapi tidak disarankan untuk mengonsumsi singkong secara mentah karena ada berbagai jenis singkong yang memiliki kadar sianida yang sangat tinggi seperti jenis Tapi Kuru 130 ppm dan jenis Ssp yang mencapai lebih dari 200 ppm kadar sianida didalam umbinya. Pada jenis singkong yang sangat beracun tersebut perlu pengolahan untuk menurunkan kadar sianidanya, tetapi apabila singkong jenis tersebut masih terasa pahit tidak disarankan untuk mengonsumsi singkong tersebut karena masih memiliki kadar sianida yang tinggi (Sunarto, 2002).

\section{KESIMPULAN}

Ada perbedaan kadar sianida antara singkong rebus dengan singkong goreng pada nilai sig. 0,012< $\alpha(0,05)$. Tidak terdapat perbedaan kadar sianida antara singkong goreng dengan singkong tanpa perlakuan yaitu pada nilai sig. $1,000<\alpha(0,05)$

\section{SARAN}

Disarankan memilih proses perebusan untuk konsumsi singkong. Peneliti selanjutnya dapat dilakukan penelitian mengenai perbandingan kadar sianida pada umbi dan daun singkong.

\section{DAFTAR PUSTAKA}

Amalia, E. R. (2011). Pengaruh Lama Perebusan dan Pengukusan Terhadap Penurunan Kadar HCN Pada Ubi Kayu Jenis Karet (Manihot glaziovii Muel). Unimus.

Baskin, S. I., Kelly, J. B., Maliner, B. I., Rock- wood, G. A., \& CK, Z. (2008). Cyanide Poisoning, In M. K. Lenhart Medical Aspects of Chemical Warfare. Houston, TX: Office of the Surgeon General, Dept. Of Army , U.S.A. and U.S. Army, Medical Dept., 371-410.

Food Standards Australia New Zealand, Cyanogenic Glycosides in Cassava and Bamboo Shoots a Human Health Risk Assessment Technical Report Series No.28. (2004). New Zaeland.

Hartati, I., Kurniasari, L., \& Yulianto, M. E. (2008). Inaktivatifati Enzimatis pada Produksi Linamarin dari Daun Singkong Sebagai Senyawa Anti Neoplastik, 4(2), 1 $-6$.

Ojiako, O. A., \& Chikezie, P. C. (2013). Cyanide and Aflatoxin Loads of Processed Cassava (Manihot esculenta) Tubers (Garri) in Njaba, Imo State, Nigeria. Jurnal Penelitian Toxicologi Internation, 20(3), 261-267.

Olorunfemi, D. I., \& Afobhokhan, C. O. (2012). Effect of selected vegetable oils on the cyanide content of cassava (Manihot esculenta Cranz.). Ife J Sci, 14, 259-267.

Panggara, H. (2010). Pengaruh Lama Fermentasi dengan Ragi Tape Terhadap Kadar Glukosa pada Umbi Gadung (Disocorea hispida DENNST). Bionature, 11(1), 7.

Pambayun, R. (2007). Kiat Sukses Teknologi Pengolahan Umbi Gadung. Yogyakarta: Ardana Media.

Purawisastra, S., Affand, i E., Almasyhuri, \& Apriyanto, R. R. (2012). Detoksifikasi dan Peningkatan Kadar Protein Singkong Pahit. Unimus.

Sunarto. (2002). Membuat Kerupuk Singkong dan Keripik Kedelai. Yogyakarta: Kanisius. 